\title{
The DNA mismatch repair gene hMSH2 is a potent coactivator of oestrogen receptor $\alpha$
}

\author{
O Wada-Hiraike, I,3, T Yano', T Nei', Y Matsumoto', K Nagasaka', S Takizawa', H Oishi' ${ }^{1,3}$, T Arimoto', \\ S Nakagawa', T Yasugi', S Kato ${ }^{2,3}$ and Y Taketani' \\ 'Department of Obstetrics and Gynecology, Graduate School of Medicine, The University of Tokyo, Hongo 7-3-I Bunkyo-ku, Tokyo II 3-8655, Japan; \\ ${ }^{2}$ SORST, Japan Science and Technology, Honcho 4-I-8, Kawaguchi, Saitama 332-00 I 2, Japan; ${ }^{3}$ Institute of Molecular and Cellular Biosciences, \\ The University of Tokyo, Yayoi I-I I Bunkyo-ku, Tokyo II 3-0034, Japan
}

The DNA mismatch repair gene is a key regulator in the elimination of base-base mismatches and insertion/deletion loops (IDLs). Human MutS homologue 2 (hMSH2), originally identified as a human homologue of the bacterial MutS, is a tumour suppressor gene frequently mutated in hereditary nonpolyposis colorectal cancer. Hereditary nonpolyposis colorectal cancer is characterised by the early onset of colorectal cancer and the development of extracolonic cancers such as endometrial, ovarian, and urological cancers. Oestrogen receptor (ER) $\alpha$ and $\beta$ are members of a nuclear receptor (NR) superfamily. Ligand-dependent transcription of ER is regulated by the $\mathrm{p} / 60$ steroid receptor coactivator family, the thyroid hormone receptor-associated proteins/the vitamin $D$ receptorinteracting proteins (TRAP/DRIP) mediator complex, and the TATA box-binding protein (TBP)-free TBP associated factor complex (TFTC) type histone acetyltransferase complex. Here, we report the interaction between ER $\alpha / \beta$ and hMSH2. Immunoprecipitation and glutathione-S-transferase pulldown assay revealed that ER $\alpha$ and hMSH2 interacted in a ligand-dependent manner, whereas ER $\beta$ and hMSH2 interacted in a ligand-independent manner. Oestrogen receptor $\alpha / \beta$ bound to hMSH2 through the hMSH3/hMSH6 interaction domain of hMSH2. In a transient expression assay, hMSH2 potentiated the transactivation function of liganded ER $\alpha$, but not that of ER $\beta$. These results suggest that $\mathrm{hMSH} 2$ may play an important role as a putative coactivator in ER $\alpha$ dependent gene expression.

British Journal of Cancer (2005) 92, 2286-229I. doi:1 0.1038/sj.bjc.66026I4 www.bjcancer.com

Published online 10 May 2005

(c) 2005 Cancer Research UK

Keywords: hMSH2; HNPCC; ER $\alpha$; ER $\beta$; coactivator; transactivation

The mismatch repair (MMR) system was originally identified in bacteria, and its inactivation results in an increase in the rate of spontaneous mutations owing to the inability to repair the replication errors. The best understood function of the MMR system is to eliminate single-base mismatches and insertiondeletion loops (IDLs) that may arise during DNA replication by DNA polymerases (Glickman and Radman, 1980; Modrich, 1997). In the first step of the repair process in humans, DNA mismatches are efficiently recognised by protein heterodimers containing human MutS homologue 2 (hMSH2). The most abundant complex is hMutS $\alpha$, a heterodimer containing hMSH2 and hMSH6. The quantitatively more minor recognition factor hMutS $\beta$ is a heterodimer comprising hMSH2 and hMSH3. The subsequent step of repair involves hMutL $\alpha$, a heterodimer comprising human MutL homologue 1 (hMLH1) and hPMS2, which interacts with hMutS $\alpha$, and directs the removal and replacement of a long stretch of DNA containing the mismatches or IDLs (Ban et al, 1999). The functions

*Correspondence: Dr O Wada-Hiraike, Department of Obstetrics and Gynecology, Graduate School of Medicine, The University of Tokyo, Hongo 7-3-I Bunkyo-ku, Tokyo II3-8655, Japan;

E-mail: owada-tky@umin.ac.jp

Received I January 2005; revised 10 March 2005; accepted 5 April 2005; published online 10 May 2005 of hMSH3 and hMSH6 are thought to be not critical for the repair of DNA mismatches because the disruption of either hMSH3 or hMSH6 leads to a mild mutator phenotype (Marsischky et al, 1996). In contrast, hMSH2 is indispensable to the recognition of mismatches and the inactivation of hMSH2 is responsible for a phenotype referred to as replication error or microsatellite instability (Bubb et al, 1996).

Hereditary nonpolyposis colorectal cancer (HNPCC) acounts for approximately $2-5 \%$ of all colorectal cancer (Mitchell et al, 2001), and remains the most common of the recognised inherited colorectal cancer syndrome. Hereditary nonpolyposis colorectal cancer is predisposed to the early onset of colorectal cancer and the development of extracolonic neoplasms including endometrial, ovarian, urological, and upper gastrointestinal cancers (RodriguezBigas et al, 1996). The identification of MMR gene mutations associated with HNPCC revealed a novel mechanism of cancer pathogenesis (Fishel et al, 1993; Leach et al, 1993). Hereditary nonpolyposis colorectal cancer is associated with germ-line mutations of the MMR genes, most commonly hMSH2 and hMLH1. The hMSH2 gene, located on chromosome 2p22-p2, consists of 15 exons and encodes a relatively large protein of 934 amino acids. The mutations of hMSH2 represent approximately $40 \%$ of the mutations detected in HNPCC kindreds. Among the 154 different hMSH2 mutations that have been analysed approximately 
$80 \%$ of the hMSH2 mutations lead to premature termination of the hMSH2 gene product. The truncated hMSH2 gene product may lose its critical functions (Drotschmann et al, 1999), which is related to the development of HNPCC.

Oestrogen receptor is a member of the nuclear hormone receptor gene superfamily and acts as a ligand-induced transcription factor (Mangelsdorf et al, 1995). Oestrogen receptor is stimulated by two distinct activation regions, activation function1 (AF-1) and AF-2. Activation function-1, which is located in the $\mathrm{N}$-terminal A/B domain, is constitutively activated in cell-type and promoter-specific manner (Metzger et al, 1995). Activation function-2 is located in the C-terminal ligand-binding domain and exerts a ligand-dependent transcriptional activation. Activation function-1 and AF-2 activate transcription independently and act synergistically (Lopez et al, 1999). Oestrogen receptor $\alpha$ contact the general transcription factors either directly or indirectly via coactivator proteins, including AF-1 coactivator p300 (Kobayashi et al, 2000) and p68/p72 (DEAD box protein) (Watanabe et al, 2001). The ligand-dependent activation of ER $\alpha$ requires liganddependent association of AF-2 coactivator complex, including p300/CBP, pCAF, the p160 family members SRC-1/TIF-2/pCIP/ AIB-1/GRIP1/ACTR (McKenna et al, 1999), the thyroid hormone receptor-associated proteins/the vitamin $\mathrm{D}$ receptor-interacting proteins (TRAP/DRIP) (Rachez et al, 2000; Kang et al, 2002), the transformation/transcription domain-associated protein (TRRAP), and the histone acetyltransferase GCN5 (Yanagisawa et al, 2002).

We have recently revealed that breast cancer susceptibility gene 1 (BRCA1), hMSH2, and GCN5 formed a complex to work on DNA repair (unpublished data). Current studies have implicated DNA repair proteins, including the $\mathrm{T}: \mathrm{G}$ mismatch specific thymine DNA glycosylase (Chen et al, 2003), and the xeroderma pigmentosum complementary group D (XPD) (Keriel et al, 2002) in the transcription regulation by nuclear receptors (NRs). On the basis of the report showing the transcriptional squelching between BRCA1 and ER $\alpha$ (Fan et al, 1999), we investigated the functional interaction between hMSH2 and ER $\alpha$.

\section{MATERIALS AND METHODS}

\section{Cell culture}

Oestrogen receptor $\alpha / \beta$-positive T-47D (HTB-133) and ER $\beta$ positive MDA-MB-231 (HTB-26) human breast cancer cell lines were purchased from the American Type Culture Collection (ATCC, Manassas, VA, USA). Oestrogen receptor $\alpha$-positive Ishikawa human endometrial cancer cell line was kindly provided by Dr M Nishida (Tsukuba University, Tsukuba, Japan), and hMSH2-deficient HEC59 human endometrial cancer cell line was a generous gift from $\mathrm{Dr} \mathrm{H}$ Kuramoto (Kitasato University, Sagamihara, Japan). These cells were maintained in Dulbecco's modified Eagle's medium (DMEM) (Sigma Aldrich, St Louis, MO, USA) supplemented with $10 \%$ fetal bovine serum (Sigma Aldrich).

\section{Immunoprecipitation}

Formation of ER $\alpha-\mathrm{hMSH} 2$ complex in Ishikawa cells and ER $\beta-$ hMSH2, BRCA1-hMSH2 (Wang et al, 2001) complex in MDA-MB231cells were analysed by co-immunoprecipitation using the specific antibody raised against human ER $\alpha$ (G-20), human ER $\beta$ (H-150), and human BRCA1 (C-20), followed by immunoblotting using the anti-hMSH2 antibody $(\mathrm{N}-20)$. All the antibodies were purchased from Santa Cruz Biotechnology (Santa Cruz, CA, USA). The $3 \times 10^{6}$ cells were suspended in $1000 \mu$ l of TNE buffer $(10 \mathrm{~mm}$ Tris- $\mathrm{HCl}$ (pH 7.8), $1 \%$ Nonidet-P40, $0.15 \mathrm{M} \mathrm{NaCl}, 1 \mathrm{~mm}$ EDTA, $1 \mu \mathrm{M}$ phenylmethylsulphonyl fluoride, and $1 \mu \mathrm{g} \mathrm{ml}^{-1}$ aprotinin). The cells were disrupted by repeated aspiration through 27-gauge needle and cellular debris were precipitated by centrifugation at
12000 r.p.m. for $30 \mathrm{~min}$ at $4^{\circ} \mathrm{C}$. The whole supernatant was applied for immunoprecipitation with $3 \mu \mathrm{g}$ of the antibodies to $\mathrm{ER} \alpha$, ER $\beta$, BRCA1, or IgG. Then, $30 \mu$ l of protein G sepharose ${ }^{\mathrm{TM}} 4$ Fast Flow (Amersham Biosciences, Buckinghamshire, UK) was added, and subsequently the bound proteins were purified as a protein complex. After washing with TNE buffer four times, the interacting proteins were separated by $7.5 \%$ SDS-polyacrylamide gel electrophoresis, transferred onto Hybond ${ }^{\mathrm{TM}}-\mathrm{ECL}^{\mathrm{TM}}$ nitrocellulose membrane (Amersham Biosciences), and detected by Western blotting with the anti-hMSH2 antibody. ECL detection was performed according to the manufacturer's recommendations.

\section{Plasmid construction}

TRAP220 and SRC-1 expression vectors were described previously (Fujita et al, 2003; Wada et al, 2004). Human MutS homologue 2 expression vector was constructed from human testis library (Clontech, Palo Alto, CA, USA). Fragments of hMSH2 were inserted into pcDNA FLAG vector derived from pcDNA 3 (Invitrogen, Carlsbad, CA, USA). Human ER $\alpha$ AF-1 (1-180), ER $\alpha$ AF-2 (263-595), ER $\beta$ AF-1 (1-149), and ER $\beta$ AF-2 (248-530) vectors were described previously (Fujita et al, 2003). Reporter constructs (17M8 $\beta$ globin-luc) have been described previously (Wada et al, 2004).

\section{Glutathione-S-transferase-pulldown assay}

Glutathione-S-transferase (GST) fusion proteins or GST alone were expressed in Escherichia coli and bound to glutathione-sepharose $4 \mathrm{~B}$ beads (Amersham Biosciences). Immobilised GST-ER $\alpha / \beta$ AF-1 or AF-2 fusion proteins were preincubated for $30 \mathrm{~min}$ in NET buffer (20 mm Tris- $\mathrm{HCl} \mathrm{pH} \mathrm{7.5,} 200 \mathrm{~mm} \mathrm{NaCl}, 1 \mathrm{~mm}$ EDTA) with or without $17-\beta$ estradiol $(10-6 \mathrm{M})$. The GST proteins were incubated at $4{ }^{\circ} \mathrm{C}$ with $\left[{ }^{35} \mathrm{~S}\right]$ methionine (Amersham Biosciences)-labeled proteins expressed by in vitro translation using the TNT-coupled transcription-translation system (Promega Co., Madison, WI, USA). After $1 \mathrm{~h}$ incubation, unbound proteins were removed by washing the beads three times in NET buffer with $0.5 \%$ Nonidet P40 and $1 \mathrm{~mm}$ phenylmethylsulphonyl fluoride. Specifically bound proteins were eluted by boiling in SDS sample buffer and analysed by $7.5-15 \%$ SDS-polyacrylamide gel electrophoresis and autoradiography. Polyacrylamide gels were stained briefly with Coomassie Brilliant Blue to verify the loading of equal amounts of fusion proteins prior to drying and autoradiography.

\section{Luciferase assay}

At 2 days before transfection, the medium was changed to phenol red-free DMEM containing 5\% charcoal stripped fetal bovine serum. Transfection was performed with PolyFect reagent (Quiagen, Inc., Chartsworth, CA, USA) according to the manufacturer's recommendations. For luciferase assay, $250 \mathrm{ng} 17 \mathrm{M} 8 \beta$-globin-luc plasmid was cotransfected with $250 \mathrm{ng}$ pM ER $\alpha$ AF-2 or pM ER $\beta$ AF-2. Indicated expression vectors were also cotransfected with ER vectors. As an internal control to equalise transfection efficiency, $5 \mathrm{ng}$ pRL CMV vector (Promega Co., Madison, WI, USA) was cotransfected in all the experiments. Individual transfections, each consisting of triplicate wells, were repeated at least three times (Wada et al, 2004).

\section{RESULTS}

\section{ER $\alpha / \beta$ and hMSH2 interacts in vivo}

To determine whether endogenous hMSH2 protein interacted with $\mathrm{ER} \alpha, \mathrm{ER} \beta$, and BRCA1 in the cultured human cells, we performed immunoprecipitation assays by using the antibodies raised against ER $\alpha$, ER $\beta$, and BRCA1. Oestrogen receptor $\alpha$ was immunopre- 
cipitated in Ishikawa cell lysate. Oestrogen receptor $\beta$ and BRCA1 were immunoprecipitated in MDA-MB-231 cell lysate. Complex formation of the precipitated proteins was confirmed by Western blotting. Immunoblotting revealed the exsistence of hMSH2 in the cell lysate immunoprecipitates (Figure 1A(i)), which supports our hypothesis that hMSH2 physically associates with ER $\alpha$ and ER $\beta$ in living cells. These results were further confirmed by reciprocal immunoprecipitation with the specific antibody raised against hMSH2. Immunoblotting again revealed the exsistence of ER $\alpha$ and ER $\beta$ (Figure $1 \mathrm{~A}(\mathrm{ii})$ ).

ER $\alpha$ and hMSH2 interact in vitro in a ligand-dependent manner, and ER $\beta$ and hMSH2 interact in vitro in a ligandindependent manner

To address the functional importance of the hMSH2-ER $\alpha$ and hMSH2-ER $\beta$ interaction, in vitro translated hMSH2 in the presence of $\left[{ }^{35} \mathrm{~S}\right]$ methionine was incubated with GST-fused ER $\alpha / \beta$ AF- 1 or ER $\alpha / \beta$ AF- 2 . As clearly shown in Figure $1 \mathrm{~B}$, the liganded GST-fused ER $\alpha$ AF-2 protein possessed the ability to retain hMSH2 on the column. On the other hand, GST-fused ER $\alpha$ AF-2 protein without the ligand, and GST-fused ER $\alpha$ AF-1 protein lacked the ability to retain hMSH2 on the column. Liganded ER $\alpha$ AF-2 possessed the ability to retain TRAP220, one of the coactivator of ER $\alpha$. These data indicated that hMSH2 directly interacts with ER $\alpha$ AF-2 in a ligand-dependent manner, similar to TRAP220. Glutathione-S-transferase-fused ER $\beta$ AF-2 protein possessed the ability to retain hMSH2 on the column regardless of the presence of ligand (Figure 1B). Glutathione- $S$-transferasefused ER $\beta$ AF- 1 protein lacked the ability to retain hMSH2 on the column. These results indicated that hMSH2 directly interacts with $\mathrm{ER} \beta \mathrm{AF}-2$ in a ligand-independent manner.

\section{Mapping of the region of hMSH2 that interacts with ER $\alpha$ AF-2 and ER $\beta$ AF-2}

To map the region of hMSH2 that interacted with ER $\alpha / \beta$ AF-2, a GST pulldown assay was performed using GST-fused ER $\alpha / \beta$ AF-2, and in vitro translated hMSH2 fragments (Figure 2). The FLAGtagged hMSH2 fragments, abbreviated 'F1' (1-178), 'F2' (179377), 'F3' (378-625), 'F4' (609-888), and 'F5' (793-934), were in vitro translated and tested for the interaction with ER $\alpha / \beta$. Only F3 region of hMSH2 interacted with $\mathrm{ER} \alpha \mathrm{AF}-2$ in a ligand-dependent manner. Thus, $\mathrm{F} 3$ of hMSH2 complexed with ER $\alpha$ via the hMSH3/ hMSH6 interaction domain. Interestingly, the liganded ER $\alpha$ column did not retain F2, which contains LXXLL motifs thought to interact with liganded NRs (Heery et al, 1997; Voegel et al, 1998). $\mathrm{F} 3$ and $\mathrm{F} 4$ regions of hMSH 2 interacted with $\mathrm{ER} \beta \mathrm{AF}-2$ in a ligandindependent manner. Thus, F3 and F4 of hMSH2 complexed with ER $\beta$ via the hMSH3/hMSH6 interaction domain.

\section{hMSH2 potentiates the transactivation function of ER $\alpha$ in a ligand-dependent manner}

To examine the coactivator activity of hMSH2 in the transactivation function of ER $\alpha / \beta$, a transient transfection assay was performed using a luciferase reporter plasmid driven by the $\beta$ globin promoter containing GAL4 DNA-binding domain. While ER $\alpha$-GAL4 fusion protein (GAL-ER $\alpha$ AF-2) showed a liganddependent transactivation function in human HEC59 endometrial cancer cells, a transient coexpression of hMSH2 led to an approximately 2.5 -fold increase in the luciferase activity compared to that of GAL-ER $\alpha$ AF-2 alone (Figure 3). The promoted transactivation function by hMSH2 was comparable to that by AF2 coactivators, SRC-1 and TRAP220. This enhancement of transactivation by hMSH2 was observed in hMSH2-deficient HEC59 cells, but not in the other cell lines, MDA-MB-231 and T47D (data not shown). The ligand-induced transactivation was not

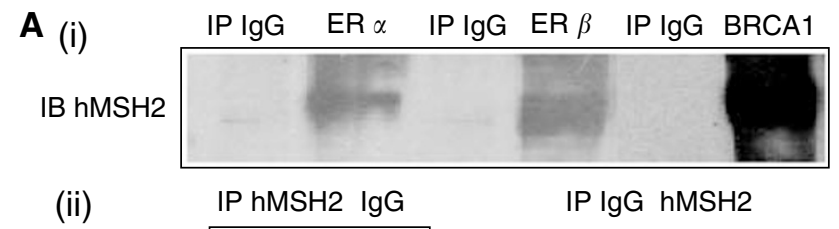

(ii)
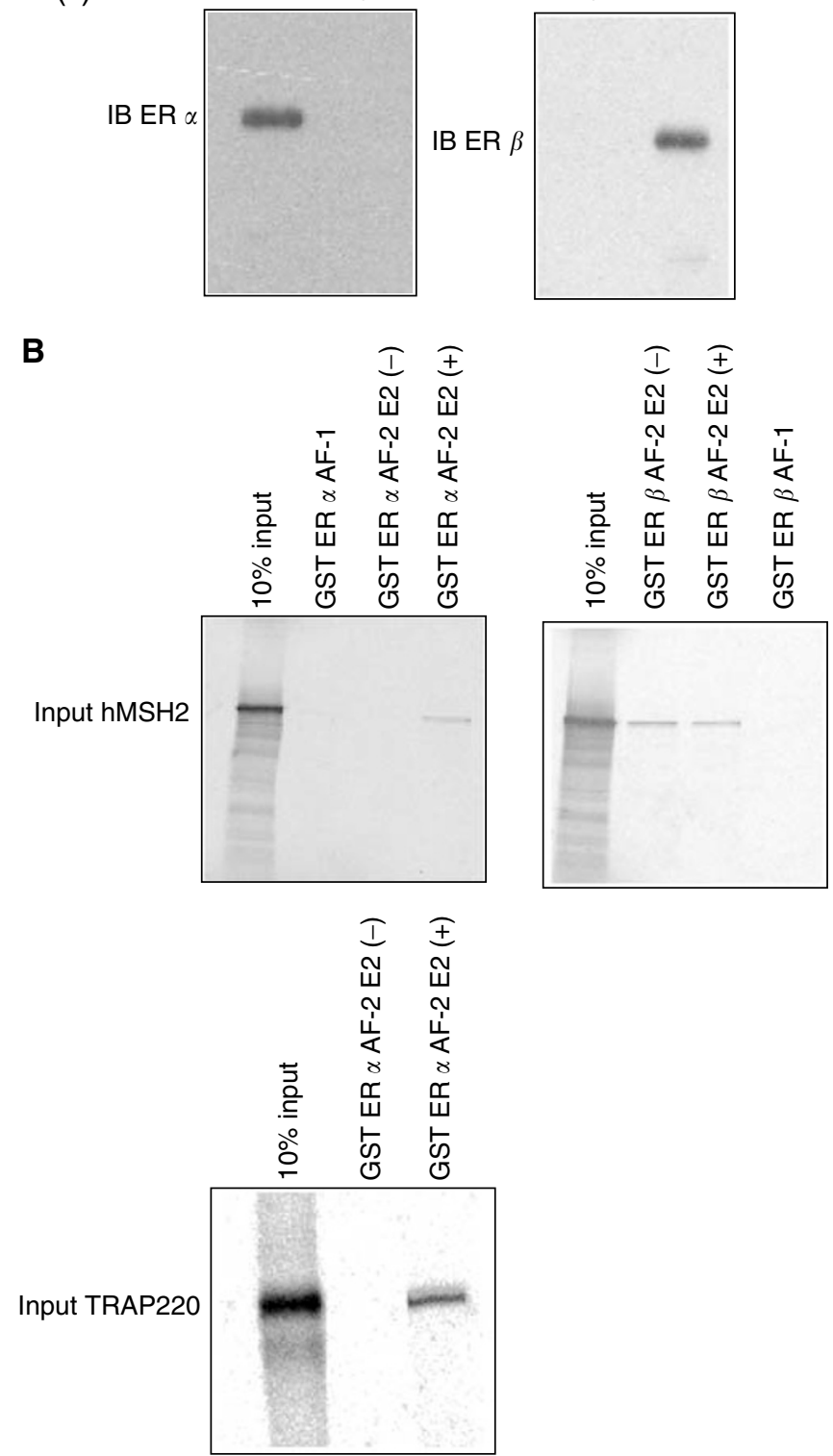

Figure I In vivo association between $\mathrm{hMSH} 2$ and $\mathrm{ER} \alpha / \beta$ and in vitro association between $\mathrm{hMSH} 2$ and $\mathrm{ER} \alpha / \beta$. (A) (i) Ishikawa cells were lysed and subjected to immunoprecipitation (IP) with the antbodies to ER $\alpha$ and IgG. MDA-MB-23| cell lysate was immunoprecipitated with the antbodies to ER $\beta$ BRCAI and $\operatorname{lgG}$. The immunoprecipitates were separated by SDSPAGE and analysed by immunoblotting (IB) with the anti-hMSH2 antibody. (ii) Reciprocal IP was performed to detect endogenous hMSH2-ER $\alpha$ and hMSH2-ER $\beta$ interactions by IB. (B) In vitro translated ${ }^{35}$ S-labelled hMSH2 was pulled down by GST-ER $\alpha / \beta$ AF-I or GST-ER $\alpha / \beta$ AF-2. At the same time, in vitro translated TRAP220 was incubated with GST-ER $\alpha$ AF-2. The mixtures were washed and subjected to SDS-PAGE and analysed.

promoted by hMSH2 when GAL-ER $\beta$ AF-2 was used (Figure 3), as expected from the in vitro ER $\alpha / \beta$ experiments. This again suggested a significant role of hMSH2 in the ligand-dependent transactivation function of ER $\alpha$. 
ER $\alpha$ and ER $\beta$ interact with hMSH2

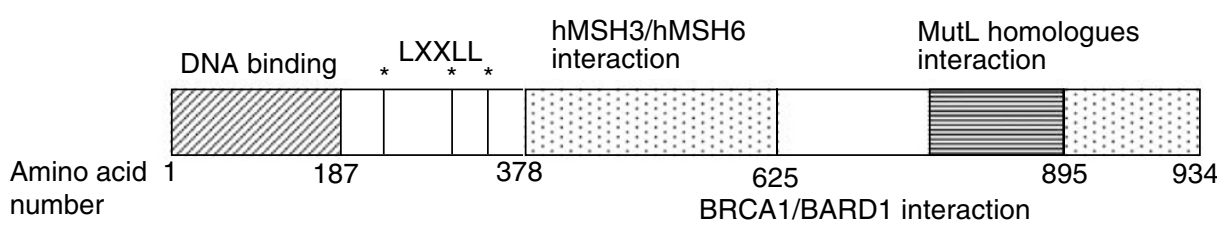

$F 1(1-178) \frac{}{F 2(179-377)}$

F3 (378-625)

F4 (609-888)

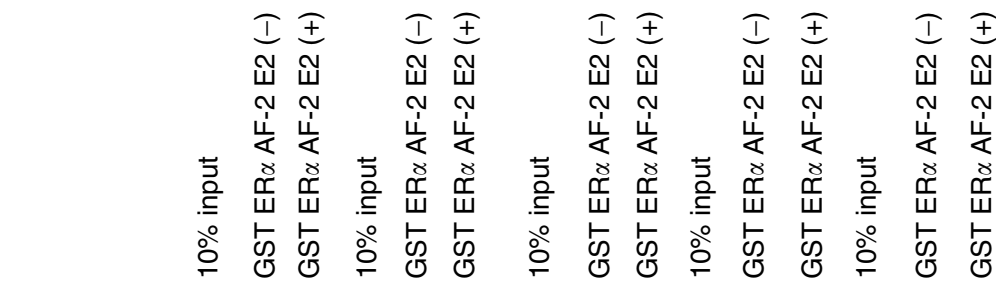

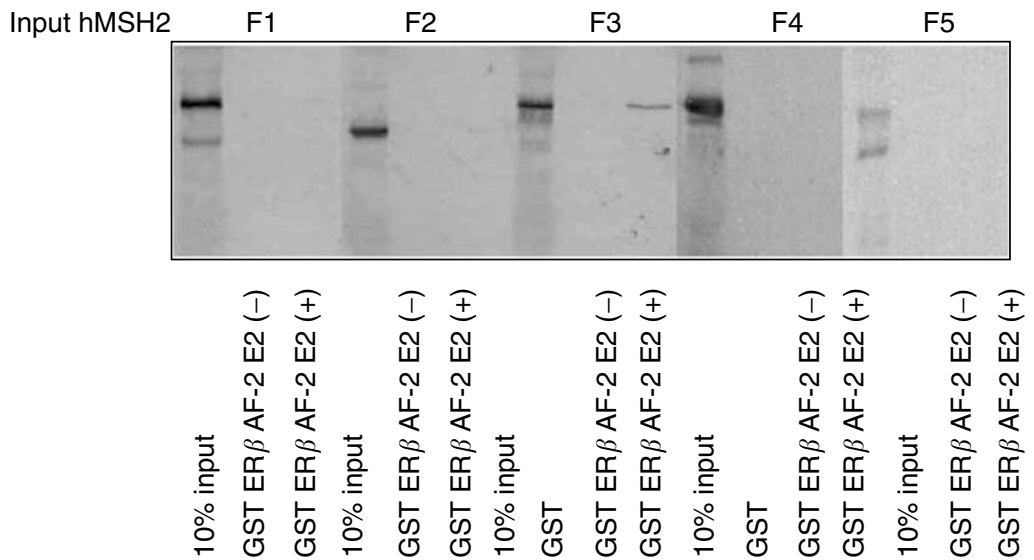

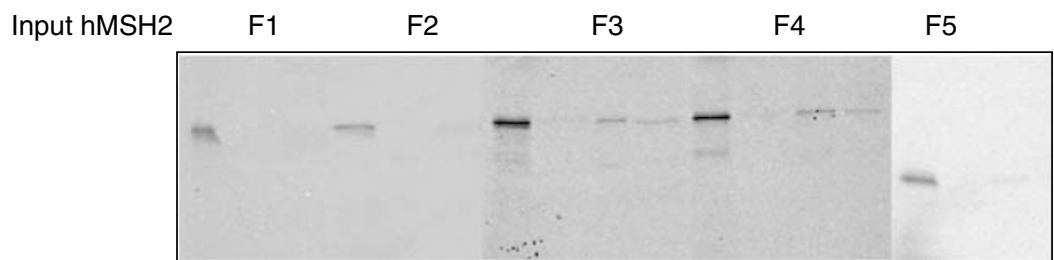

Figure 2 Mapping of the $\mathrm{ER} \alpha / \beta$-interacting region of $\mathrm{hMSH} 2$. A schematic diagram of the structure of hMSH2 is shown. ' $\mathrm{Fl}$ ', ' $\mathrm{F} 2$ ', ' $\mathrm{F} 3$ ', ' $F 4$ ', and ' $\mathrm{F} 5$ ' fragments of hMSH2 were in vitro translated. In view of the result of Figure I, the fragments of hMSH2 and GST-ER $\alpha / \beta$ AF- 2 were tested for detection. The mixtures were washed and subjected to SDS-PAGE and then visualised by autoradiography.

\section{DISCUSSION}

We showed that endogenous ER $\alpha / \beta$ associated with wild-type hMSH2 in the cultured human cells. Immunoblotting revealed the exsistence of hMSH2 in the cell lysate immunoprecipitates, which was confirmed by reciprocal immunoprecipitation with the specific antibody raised against hMSH2. The direct interaction between ER $\alpha / \beta$ and hMSH2 was investigated by GST pulldown assays. The GST-fused ER $\alpha$ AF- 2 protein showed the ability to retain hMSH2 in a ligand-dependent manner. F3 region of hMSH2 interacted with ER $\alpha$ AF-2 in a ligand-dependent manner, which was supported by the findings that ER $\alpha$ alone potently enhanced $\mathrm{hMSH} 2$ transactivation function. In contrast, F3 and F4 regions of hMSH2 interacted with ER $\beta$ AF-2 in a ligand-independent manner, and ER $\beta$ lacked the ability to enhance hMSH2 transactivation function. These results indicated that the ER $\alpha / \beta$ containing complexes might play a role in the MMR system of hMSH2.
Ligand-dependent interaction of hMSH2 was identified as a unique property because hMSH2 directly binds to ER $\alpha$ AF- 2 as if hMSH2 acts as an ER coactivator. Although hMSH2 has three NR recognition motifs (LXXLL, NR box), these motifs have no significant role in the binding of ER $\alpha$ and ER $\beta$. Given that hMSH2 may promote gene regulation with ERs, and that the mutations in hMSH2 may lead to an altered ER $\alpha$-dependent gene regulation and an altered tumorigenesis in oestrogen-dependent cancers (presumably through the modulation of ER-mediated oestrogen signalling), the interaction between ER $\alpha / \beta$ and hMSH2 may partially account for the relationship between HNPCC and oestrogen-dependent extracolonic tumours such as endometrial cancer. Our results also indicated that hMSH2 competed with ER $\alpha$ in terms of transcriptional control via the hMSH3/hMSH6 interaction domain of $\mathrm{hMSH} 2$, which suggestes the possibility that the common coactivator complexes of ER, including the p160 family complex, TRAP/DRIP complex and TFTC complex, might have a functional relationship with the MMR complex. 


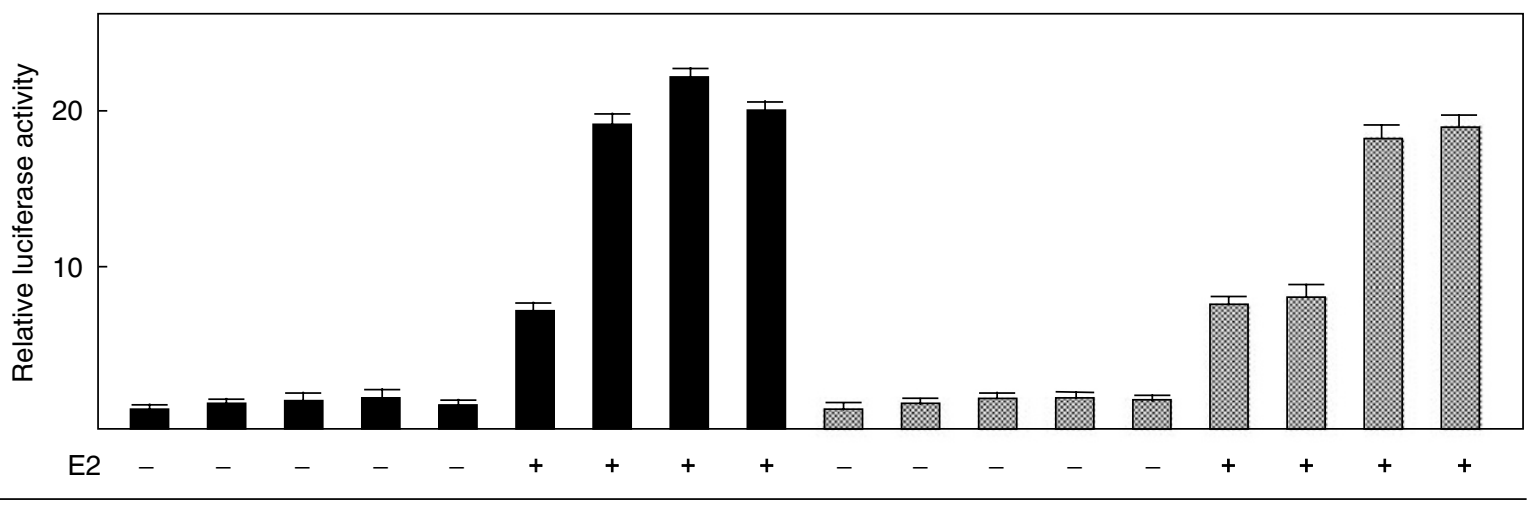

\begin{tabular}{|c|c|c|c|c|c|c|c|c|c|c|c|c|c|c|c|c|c|c|}
\hline pM ER $\alpha$ AF-2 & + & + & + & + & + & + & + & + & + & - & - & - & - & - & - & - & - & - \\
\hline pM ER $\beta$ AF-2 & - & - & - & - & - & - & - & - & - & + & + & + & + & + & + & + & + & + \\
\hline pcDNA3 & - & + & - & - & - & + & - & - & - & - & + & - & - & - & + & - & - & - \\
\hline pcDNA hMSH2 & - & - & + & - & - & - & + & - & - & - & - & + & - & - & - & + & - & - \\
\hline pcDNA SRC-1 & - & - & - & + & - & - & - & + & - & - & - & - & + & - & - & - & + & - \\
\hline pcDNA TRAP 220 & - & - & - & - & + & - & - & - & + & - & - & - & - & + & - & - & - & + \\
\hline
\end{tabular}

Figure 3 Activation of transcription by ER $\alpha$ AF-2 by the overexpression of $\mathrm{hMSH} 2$ in a ligand-dependent manner. HEC59 cells were transfected with pM ER $\alpha / \beta$ AF-2 (250 ng), I $7 M 8$-globin-luc (250 ng), pRL CMV-Luc (5 ng), pcDNA (I 00 ng), pcDNA hMSH2 (I00 ng), pcDNA SRC-I (I 00 ng), and pcDNA TRAP220 (100 ng) in the presence of $17-\beta$ estradiol at $10^{-8} \mathrm{M}$, and cell extracts were used for luciferase assay. Results are shown as the mean \pm s.d. SRC-I, TRAP 220, and hMSH2 caused a ligand-dependent potentiation of the ER $\alpha$ transactivation function.

Oestrogen stimulates diverse biological effects in humans, and many of these effects result from a direct interaction of oestrogen with an NR that activates the expression of genes encoding proteins with important biological functions. Oestrogen has a mitogenic action in hormone-sensitive tissues such as the uterus. In addition to this action, oestrogen possesses carcinogenic activity. Prolonged exposure to oestrogen without opposing by progesterone is considered to cause endometrial hyperplasia and endometrioid adenocarcinoma in relatively young women. The interaction between ER $\alpha / \beta$ and hMSH2 might have a significant role in the pathogenesis of endometrial cancer. Recently, it was reported that not only tamoxifen, a selective oestrogen receptor modulator (SERM) used in the treatment of breast cancer, but also oestrogen derivatives possess a high mutagenic potential (Mizutani et al, 2004), which is attained by two mechanisms. First, DNA replication blocks may cause chromosomal breaks and lead to translocation or large deletion. Second, the employment of errorprone translesion DNA synthesis polymerases to bypass DNA damage is likely to result in an accumulation of point mutations. On the other hand, withdrawal of oestrogen may increase a risk of microsatellite instability-positive colon cancer based on the epidemiological data (Slattery et al, 2001). Considering the present data, ER itself may have a fuctional role in DNA MMR. Especially, ER $\beta$, which is expressed in colon cancer (Gustafsson, 2003), may have a potent role through the ligand-independent interaction with hMSH2.

\section{REFERENCES}

Ban C, Junop M, Yang W (1999) Transformation of MutL by ATP binding and hydrolysis: a switch in DNA mismatch repair. Cell 97: 85-97

Bubb VJ, Curtis LJ, Cunningham C, Dunlop MG, Carothers AD, Morris RG, White S, Bird CC, Wyllie AH (1996) Microsatellite instability and the role of hMSH2 in sporadic colorectalcancer. Oncogene 20: 2641-2649

Chen D, Lucey MJ, Phoenix F, Lopez-Garcia J, Hart SM, Losson R, Buluwela L, Coombes RC, Chambon P, Schar P, Ali S (2003) T:G mismatch-specific
The present study showed that ER $\alpha / \beta$ bound directly to wildtype hMSH2. Considering the fact that most mutations found in the patients of HNPCC result in a premature truncation of hMSH2, the loss of hMSH3/hMSH6 interaction domain in hMSH2 may result in a loss of interaction between ER $\alpha / \beta$ and hMSH2. In this respect, the functional interaction between $\mathrm{ER} \alpha / \beta$ and hMSH 2 may be required to prevent or promote the progression in the pathogenesis of endometrial cancer complicating HNPCC. Our transient transfection assay showed that the MMR complex clearly served as a coactivator complex in the promoters of ER $\alpha$ target genes because hMSH2 enhanced ER $\alpha$-mediated ligand-dependent transactivation function. Further investigations should be performed to elucidate the molecular mechanisms that underlie the formation of $\mathrm{ER} \alpha / \beta$-hMSH 2 complexes in normal cell growth, thereby revealing hMSH2 as a tumour suppressor in oestrogenresponsive organs, especially the endometrium. In conclusion, these results suggest that the failure of binding between hMSH2 and ER $\alpha / \beta$ may be a key event in cancer predisposition.

\section{ACKNOWLEDGEMENTS}

This study was supported by a Grant-in-aid (No. 16790939, OW-H) for Scientific Research from the Ministry of Education, Science and Culture, Japan.
thymine-DNA glycosylase potentiates transcription of estrogen-regulated genes through direct interaction with estrogen receptor alpha. J Biol Chem 278: 38586-38592

Drotschmann K, Clark AB, Tran HT, Resnick MA, Gordenin DA, Kunkel TA (1999) Mutator phenotypes of yeast strains heterozygous for mutations in the MSH2 gene. Proc Natl Acad Sci USA 96: $2970-2975$ 
Fan S, Wang J, Yuan R, Ma Y, Meng Q, Erdos MR, Pestell RG, Yuan F, Auborn KJ, Goldberg ID, Rosen EM (1999) BRCA1 inhibition of estrogen receptor signaling in transfected cells. Science 284: 1354-1356

Fishel R, Lescoe MK, Rao MR, Copeland NG, Jenkins NA, Garber J, Kane M, Kolodner R (1993) The human mutator gene homolog MSH2 and its association with hereditary nonpolyposis colon cancer. Cell 75: 1027- 1038

Fujita T, Kobayashi Y, Wada O, Tateishi Y, Kitada L, Yamamoto Y, Takashima H, Murayama A, Yano T, Baba T, Kato S, Kawabe Y, Yanagisawa J (2003) Full activation of estrogen receptor alpha activation function-1 induces proliferation of breast cancer cells. J Biol Chem 278: $26704-26714$

Glickman BW, Radman M (1980) Escherichia coli mutator mutants deficient in methylation-instructed DNA mismatch correction. Proc Natl Acad Sci USA 77: $1063-1067$

Gustafsson JA (2003) What pharmacologists can learn from recent advances in estrogen signalling. Trends Pharmacol Sci 24: 479-485

Heery DM, Kalkhoven E, Hoare S, Parker MG (1997) A signature motif in transcriptional co-activators mediates binding to nuclear receptors. Nature 387: $733-736$

Kang YK, Guermah M, Yuan CX, Roeder RG (2002) The TRAP/Mediator coactivator complex interacts directly with estrogen receptors alpha and beta through the TRAP220 subunit and directly enhances estrogen receptor function in vitro. Proc Natl Acad Sci USA 99: 2642-2647

Keriel A, Stary A, Sarasin A, Rochette-Egly C, Egly JM (2002) XPD mutations prevent TFIIH-dependent transactivation by nuclear receptors and phosphorylation of RARalpha. Cell 1: 125-135

Kobayashi Y, Kitamoto T, Masuhiro Y, Watanabe M, Kase T, Metzger D, Yanagisawa J, Kato S (2000) p300 mediates functional synergism between AF-1 and AF-2 of estrogen receptor alpha and beta by interacting directly with the N-terminal A/B domains. J Biol Chem 275: 15645-15651

Leach FS, Nicolaides NC, Papadopoulos N, Liu B, Jen J, Parsons R, Peltomäki P, Sistonen P, Aaltonen LA, Nyström-Lahti M, Guan XY, Zhang J, Meltzer PS, Yu JW, Kao FT, Chen DJ, Cerosaletti KM, Fournier REK, Todd S, Lewis T, Leach RJ, Naylor SL, Weissenbach J, Mecklin J-P, Järvinen H, Petersen GM, Hamilton SR, Green J, Jass J, Watson P, Lynch HT, Trent JM, Chapelle A, Kinzler KW, Vogelstein B (1993) Mutations of a MUTS homolog in hereditary nonpolyposis colorectal cancer. Cell 75: $1215-1225$

Lopez GN, Webb P, Shinsako JH, Baxter JD, Greene GL, Kushner PJ (1999) Titration by estrogen receptor activation function- 2 of targets that are downstream from coactivators. Mol Endocrinol 13: 897-909

Mangelsdorf DJ, Thummel C, Beato M, Herrlich P, Schutz G, Umesono K, Blumberg B, Kastner P, Mark M, Chambon P, Evans RM (1995) The nuclear receptor superfamily: the second decade. Cell 86(6): 835-839

Marsischky GT, Filosi N, Kane MF, Kolodner R (1996) Redundancy of Saccharomyces cerevisiae MSH3 and MSH6 in MSH2-dependent mismatch repair. Genes Dev 10: 407-420
McKenna NJ, Lanz RB, O’Malley BW (1999) Nuclear receptor coregulators: cellular and molecular biology. Endocr Rev 20: 321-344

Metzger D, Ali S, Bornert JM, Chambon P (1995) Characterization of the amino-terminal transcriptional activation function of the human estrogen receptor in animal and yeast cells. $J$ Biol Chem 270: $9535-9542$

Mitchell RJ, Farrington SM, Dunlop MG, Campbell H (2001) Mismatch repair genes hMLH1 and hMSH2 and colorectal cancer. Am J Epidemiol 156: $885-902$

Mizutani A, Okada T, Shibutani S, Sonoda E, Hochegger H, Nishigori C, Miyachi Y, Takeda S, Yamazoe M (2004) Extensive chromosomal breaks are induced by tamoxifen and estrogen in DNA repair-deficient cells. Cancer Res 64: $3144-3147$

Modrich P (1997) Strand-specific mismatch repair in mammalian cells. $J$ Biol Chem 272: 24727 - 24730

Rachez C, Gamble M, Chang CP, Atkins GB, Lazar MA, Freedman LP (2000) The DRIP complex and SRC-1/p160 coactivators share similar nuclear receptor binding determinants but constitute functionally distinct complexes. Mol Cell Biol 20: 2718-2726

Rodriguez-Bigas MA, Lee PH, O'Malley L, Weber TK, Suh O, Anderson GR, Petrelli NJ (1996) Establishment of a hereditary nonpolyposis colorectal cancer registry. Dis Colon Rectum 39: 649-653

Slattery ML, Potter JD, Curtin K, Edwards S, Ma KN, Anderson K, Schaffer D, Samowitz WS (2001) Estrogens reduce and withdrawal of estrogens increase risk of microsatellite instability-positive colon cancer. Cancer Res 61: $126-130$

Voegel JJ, Heine MJ, Tini M, Vivat V, Chambon P, Gronemeyer H (1998) The coactivator TIF2 contains three nuclear receptor-binding motifs and mediates transactivation through CBP binding-dependent and -independent pathways. EMBO J 17: 507-519

Wada O, Oishi H, Takada I, Yanagisawa J, Yano T, Kato S (2004) BRCA1 function mediates a TRAP/DRIP complex through direct interaction with TRAP220. Oncogene 23: 6000-6005

Wang Q, Zhang H, Guerrette S, Chen J, Mazurek A, Wilson T, Slupianek A, Skorski T, Fishel R, Greene MI (2001) Adenosine nucleotide modulates the physical interaction between hMSH2 and BRCA1. Oncogene 20: $4640-4649$

Watanabe M, Yanagisawa J, Kitagawa H, Takeyama K, Ogawa S, Arao Y, Suzawa M, Kobayashi Y, Yano T, Yoshikawa H, Masuhiro Y, Kato S (2001) A subfamily of RNA-binding DEAD-box proteins acts as an estrogen receptor alpha coactivator through the $\mathrm{N}$-terminal activation domain (AF-1) with an RNA coactivator, SRA. EMBO J 20: $1341-1352$

Yanagisawa J, Kitagawa H, Yanagida M, Wada O, Ogawa S, Nakagomi M, Oishi H, Yamamoto Y, Nagasawa H, McMahon SB, Cole MD, Tora L, Takahashi N, Kato S (2002) Nuclear receptor function requires a TFTCtype histone acetyl transferase complex. Mol Cell 9: 553-562 